\title{
Scientific Article \\ In vitro culture and greenhouse acclimatization of Oncidium varicosum (Orchidaceae) with microorganisms isolated from its roots
}

\author{
Gabrielle Alves Bezerra $^{1}$; Afra Vital Matos Dias Gabriel²; Eduardo D. Mariano²; Jean Carlos Cardoso ${ }^{3 *}$
}

\begin{abstract}
Sustainable production of orchids may be achieved with the use of symbiotic microorganisms that improve resistance of plants to pests and diseases and reduce the need of substrate fertilization. In this study, one fungus (F1), one yeast (Y1) and one grampositive bacteria $(\mathrm{B}+)$ were isolated from the roots of the orchid Oncidium varicosum and used in the cultivation of protocorms and plantlets obtained from seeds of this species. Cultivation of protocorms in Murashige and Skoog (MS) medium enriched with sucrose and inoculated with microorganisms did not result in better development of protocorms. However, the use of plantlets in the rooting phase in MS medium without sucrose and inoculated with B+ resulted in plantlets with more leaves and roots and longer shoots and roots, suggesting synergism between microorganism and plant when sucrose is absent. The major benefits of co-cultivating plantlets and these microorganisms were observed in the acclimatization in the greenhouse. Plantlets obtained with oat meal agar medium and $\mathrm{B}+$ showed the highest pseudobulb diameter, number of roots, height and fresh weight among treatments. We concluded that the application of rooting-derived microorganisms in the in vitro culture and plantlet acclimatization of Oncidium varicosum is beneficial.
\end{abstract}

Keywords: co-culture, in vitro seedling development, microorganisms, synergism, acclimatization, conservation

\section{Resumo}

Cultivo in vitro e aclimatização em casa de vegetação de orquídea Oncidium varicosum com microrganismos isolados de suas raízes

O emprego de microrganismos na micropropagação de plantas de orquídeas pode melhorar a produção de mudas por aumentar a resistência das plantas a doenças e diminuir o requerimento de fertilizantes. Neste estudo, um fungo (F1), uma levedura (L1) e uma bactéria gram-positiva $(\mathrm{B}+)$ foram isolados de raízes da orquídea Oncidium varicosum e empregados no cultivo in vitro de protocormos e plântulas obtidos de sementes desta espécie. No primeiro ensaio, o meio Murashige \& Skoog (MS) enriquecido com sacarose e inoculado individualmente com os microorganismos não proporcionou melhoria no desenvolvimento dos protocormos do que o meio sem microrganismos. No segundo ensaio, com plântulas em início de enraizamento e com três meios de cultura, o meio MS sem sacarose inoculado com B+ proporcionou aumento no número médio de folhas $(3,8$ para 7,5$)$, raízes $(4,0$ para 12,1) e comprimento da maior raiz $(1,1$ para $6,4 \mathrm{~cm})$ por planta, comparado ao meio sem a bactéria, sugerindo sinergismo entre plantas e o microrganismo na ausência de sacarose no meio. Na aclimatização em casa de vegetação, plântulas advindas do meio aveia-ágar inoculado com B+ apresentaram o maior diâmetro de pseudobulbo, número de raízes, altura e massa fresca entre os tratamentos. Conclui-se que há potencial de aplicação de microrganismos para melhorar a produção de mudas de O. varicosum.

Palavras-chaves: co-cultivo, desenvolvimento in vitro, microrganismos, conservação, aclimatização, sinergismo

\footnotetext{
${ }^{1}$ Federal University of São Carlos (UFSCar), Center of Agricultural Sciences (CCA), Araras-SP, Brazil.

${ }^{2}$ Federal University of São Carlos (UFSCar), Center of Agricultural Sciences (CCA), Department of Rural Development, Araras-SP, Brazil.

${ }^{3}$ Federal University of São Carlos (UFSCar), Center of Agricultural Sciences (CCA), Department of Biotechnology, Plant and Animal Production, Araras-SP, Brazil.*Corresponding author: jeancardoso@ufscar.br
} 


\section{Introduction}

Oncidium varicosum Lindl. is an epiphytic orchid species that occurs naturally in forests and forest remnants of the Atlantic forest biome. The plants have long inflorescences that hold a great number of yellow flowers with brown spots on their petals and sepals. The labellum is much bigger than the other flower parts, which, in combination with its intense yellow colour confers great prominence to the flower. Oncidium species and hybrids are among the most economically important plant species in floriculture (Faria and Colombo, 2015; Cardoso, 2017).

O. varicosum, similarly to other orchid species, has been facing a large reduction of its natural environment due to human activities such as agriculture, cattle raising and construction of small hydroelectric power stations (Cardoso et al., 2016). In addition, due to its great ornamental value, plants of such species have been overcollected for commercial and personal use. Reduction of the environment to small forest remnants and climate change not only reduce conditions for the natural development of this species but also isolate groups of few individuals and reduce pollination, which narrows the genetic variability of the population (Novello et al., 2013; Pinheiro et al., 2013).

In vitro germination of orchids seeds and subsequent acclimatization of plantlets under environmentally controlled conditions, might be an alternative to producing large amounts of individuals with the aim of conserving and reintroducing plants in nature $\mathrm{Wu}$ et al., 2014) and increasing the efficiency of orchid breeding programs (Cardoso, 2017). Besides being beneficial for the in vitro germination of seeds and acclimatization, the co-cultivation of the plantlets with symbiotic microorganisms obtained from roots of orchid plants may be indispensable to increase plantlet growth and plant survival (Silva et al., 2016).

Recent studies support the hypothesis of true mutualism between orchids and mycorrhizal fungi, in all stages of development, including the non-photosynthetic protocormstage, where orchids must pass ammonium to the fungus, in return for nutrients, such as $\mathrm{C}, \mathrm{N}$ and $\mathrm{P}$, and water (Dearnaley and Cameron, 2016). In addition, endophytic fungi in orchids can have antimicrobial activity and play a role against pathogens (Jin et al. 2017).

The objectives of this work were to isolate microorganisms from roots of adult plants of $O$. varicosum, study their effects on growth of plantlets during in vitro culture and greenhouse acclimatization and establish a symbiotic culture protocol for this species.

\section{Material and Methods}

Isolation, culture and selection of microorganisms from Oncidium roots

Five roots per individual of one adult individuals of Oncidium varicosum growing in forest remnants in southwestern Minas Gerais and north-eastern Sao Paulo were collected and thoroughly rinsed in tap water. To disinfect their surface, roots were immersed for one min in $70 \%$ ethanol and for $15 \mathrm{~min}$ in $2.5 \%$ sodium hypochlorite water solution and then rinsed several times with sterile demineralised water. Microorganisms living inside the roots were isolated from transversal as well as longitudinal cuts of 1-cm long root pieces and inoculated in two different potato dextrose agar (PDA) culture media in Petri dishes (see below).

A PDA medium with $20 \mathrm{~g} \mathrm{~L}^{-1}$ of glucose and $18 \mathrm{~g} \mathrm{~L}^{-1}$ of agar was used as the basal medium. The liquid medium was adjusted to $\mathrm{pH} 5.6$ and autoclaved at $120{ }^{\circ} \mathrm{C}$ for $20 \mathrm{~min}$. A second, selective, PDA medium was prepared with the addition of Rose Bengal dye (1 mg/L) before autoclaving, and of streptomycin $(1 \mathrm{mg} / \mathrm{L})$ after autoclaving. The roots of $O$. varicosum were then inoculated and kept in a growth room at $25 \pm 2{ }^{\circ} \mathrm{C}$ for five days.

Microorganisms grown on the basal PDA medium were replicated to Petri dishes containing PDA or MS (Murashige and Skoog, 1962) medium and were kept in a growth room at $25 \pm 2{ }^{\circ} \mathrm{C}$ for 7 days. The first PDA culture medium was used as control, but the MS medium normally used for in vitro plant tissue culture was also used for microorganism cultivation in order to evaluate which media provides the best growth for later inoculation of plants with microorganisms.

All colonies of selected microorganisms were collected and transferred to $15 \mathrm{~mL}$ plastic tubes with sterile demineralized water and stored at $8{ }^{\circ} \mathrm{C}$ in the refrigerator until use (permanent colonies).

\section{In vitro asymbiotic seed germination of Oncidium varicosum}

Seeds of Oncidium varicosum were collected from fruits of the same plants used for microorganisms isolation, left at room temperature for 24-hours to dry, and then stored in $1.5 \mathrm{~mL}$ plastic tubes at $8^{\circ} \mathrm{C}$. To sterilize the surface of the seeds they were immersed for $10 \mathrm{~min}$ in a $0.25 \%$ sodium hypochlorite water solution and subsequently rinsed three times with sterile demineralised water. The seeds were laid on the surface of the sterile germination medium, which consisted of an MS medium containing 50\% of the concentration of macronutrients $\left(\mathrm{MS}^{1} / 2\right), 20 \mathrm{~g} \mathrm{~L}^{-1}$ of sucrose, $0.1 \mathrm{~g} \mathrm{~L}^{-1}$ of myo-inositol, and $6.4 \mathrm{~g} \mathrm{~L}^{-1}$ of agar. The medium $\mathrm{pH}$ was adjusted to 5.6, the agar was added and the medium autoclaved at $120{ }^{\circ} \mathrm{C}$ for $20 \mathrm{~min}$. Petri dishes with $15 \mathrm{~mL}$ of medium and seeds were maintained for 14 days under low light intensity ( $<300$ lux) and for 75 days under a higher light intensity (1000-1500 lux) for germination and protocorm development at $26{ }^{\circ} \mathrm{C}$ with lamps fluorescent lights, 14-hours photoperiod.

\section{Symbiotic culture of protocorms and plantlets of} Oncidium varicosum

To test the effects of the microorganisms isolated from roots on growth of Oncidium varicosum seedlings, two experiments were conducted. The following treatments were tested: three microorganisms isolated from roots (one fungus and two yeasts), three culture media (MS1/2, MS1/2 with sucrose, and oatmeal agar (OMA) medium) and two developmental stages (protocorms and plantlets) at which 
the microorganisms were introduced in the culture media. In the first experiment, protocorms at the differentiation stage of development, with leaves of $1.0 \pm 0.2 \mathrm{~cm}$ length, were used. Protocorms were added to $300 \mathrm{~mL}$ glass bottles containing $30 \mathrm{~mL}$ of MS $1 / 2$ medium enriched with $20 \mathrm{~g} \mathrm{~L}^{-1}$ of sucrose and inoculated individually with each one of the three microorganisms selected (see below the inoculation procedure). In the second experiment, plantlets with an average length of $2.0 \pm 0.2 \mathrm{~cm}$ and showing root initiation were cultured in three different media: 1) MS $1 / 2$ sucrosefree; 2) $\mathrm{MS}^{1} \frac{1}{2}$ with $20 \mathrm{~g} \mathrm{~L}^{-1}$ of sucrose; and 3) OMA medium (40 g oat, $20 \mathrm{~g}$ glucose, $15 \mathrm{~g}$ agar, $1 \mathrm{~L}$ demineralised water) inoculated individually with each one of the three microorganisms selected (see below the inoculation procedure).

For microorganism inoculation, pieces of one square centimetre of the border of the microorganism colonies grown on PDA medium were cut and added to a flask containing $10 \mathrm{~mL}$ sterile demineralised water. After gentle agitation of the flask for $1 \mathrm{~min}, 1 \mathrm{~mL}$ of the solution was pipetted into the glass bottles containing the protocorms or plantlets of $O$. varicosum. Control bottles (asymbiotic culture) received $1 \mathrm{~mL}$ of pure sterile water.

In each experiment, there were three replicate glass bottles per treatment and the bottles were randomly distributed in the growth room at $26^{\circ} \mathrm{C}$ with lamps fluorescent lights, 14-hours photoperiod. The first experiment had 25 protocorms per bottle whereas the second one had two plantlets per bottle. In both experiments, individuals were evaluated after 90 days of cultivation. Ten protocorms ( $1^{\text {st }}$ experiment) and two plantlets ( $2^{\text {nd }}$ experiment) were randomly removed from each replicate bottle and measured for height, number of leaves, number of roots, length of the longest root and fresh weight.

\section{Acclimatization of plantlets in greenhouse}

After measurements, plantlets of the second experiment were transplanted to trays whose cells were filled with an autoclaved solid substrate composed of ground pine bark.
The trays with plants were kept in a growth room at 26 ${ }^{\circ} \mathrm{C}$ for 30 days and then transferred to a greenhouse for acclimatization. In the greenhouse, closed with a $150 \mu \mathrm{m}$ thick plastic on top and with an anti-aphid net on laterals, the plants were maintained under a $70 \%$ shade. Water was provided by an automated microaspersion irrigation system that applied $4 \mathrm{~L}$ of water per square meter per day. Five plants were evaluated per treatment after 180 days of growth and the experiment was carried out twice.

Analyses of variance and mean tests were performed for all plant variables measured. Residual analysis was performed to confirm the adequacy of the statistical model and to detect violations of the assumptions underlying the random errors. All analyses were computed with the $\mathrm{R}$ software.

\section{Results and Discussion}

Isolation, culture and selection of microorganisms from Oncidium roots

Seven different colonies grew in common PDA medium and four different ones in the selective PDA medium ( + rose bengal and streptomycin). There were three colonies of fungi, three of yeast and one of bacteria in the common PDA medium and two colonies of fungi, one of yeast and one of bacteria in the selective PDA medium. Because some colonies were visually like each other, only microorganisms of different colonies were selected to be further tested. Fungus 1 (Figure 1D) was selected because of the $90^{\circ}$ ramification of its hyphae (Figure $1 \mathrm{E}$ ), which is like those ramifications seen in mycorrhizal fungi found in other orchid species (Pereira et al., 2018). One yeast isolated from roots, Y1 (Figure 1B) and one gram positive bacteria $(\mathrm{B}+)$ (Figure 1C), were selected because of the potential of yeast and bacteria to enhance plant growth (Ignatova et al., 2015; Gontijo et al., 2018) and because there is very little information on beneficial interactions between orchids and yeast and orchid and bacteria (Silva et al., 2015). 

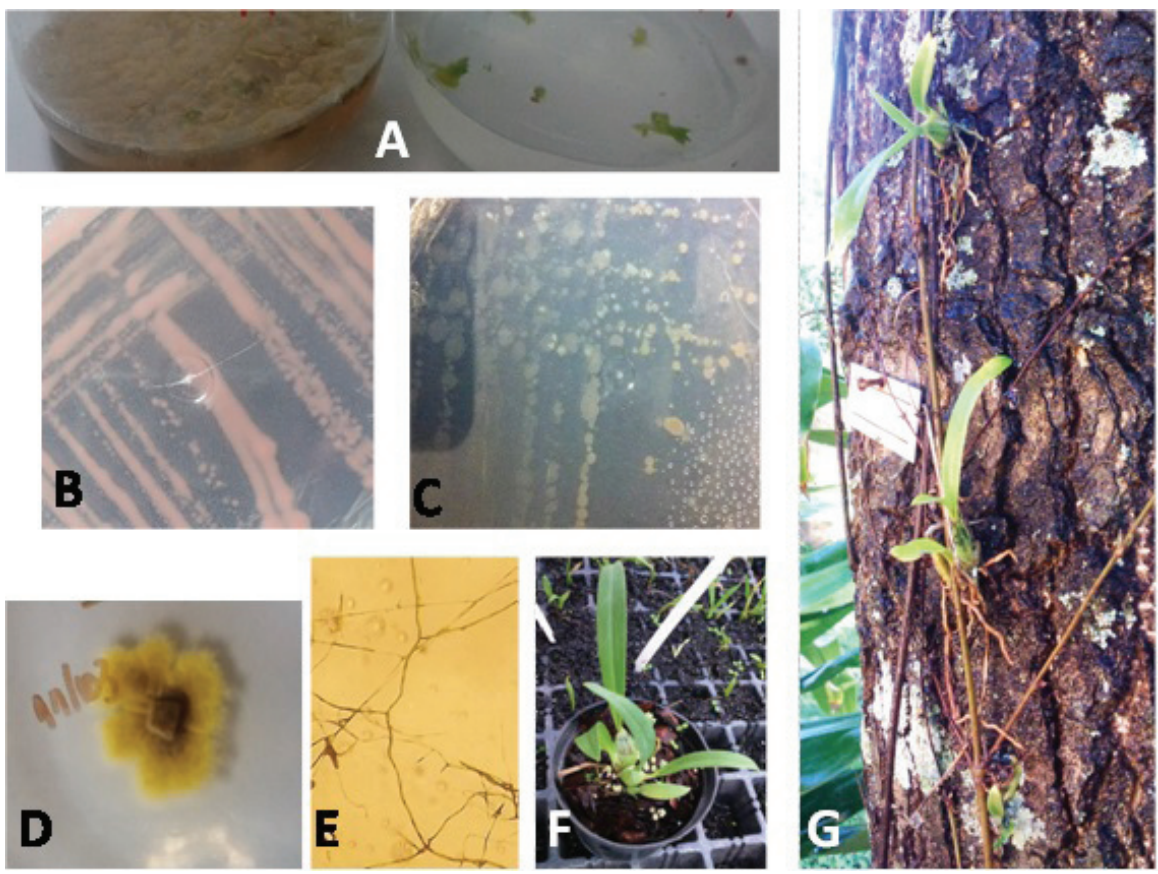

Figure 1. Microorganisms isolated from roots of adult plant of $O$. varicosum in PDA medium and co-cultivated in vitro with plantlets of $O$. varicosum: A, protocorm of $O$. varicosum co-cultivated with fungus in $\mathrm{MS}^{1} / 2$ + sucrose culture medium (left) and without micro-organisms (right); Colony characteristics of yeast 1 (B) and grampositive bacteria $(\mathrm{C})$ isolated from the roots of $O$. varicosum and grown on PDA medium; Fungus 1 grown on PDA medium (D) and hyphae under light microscopy (E); F, acclimatized plantlet after six months of cultivation in ground pine bark substrate in the greenhouse; and $\mathrm{G}$, plantlet inoculated with bacteria $\mathrm{B}(+)$ and used for restoration of a riparian forest in Araras-SP, Brazil.

In vitro asymbiotic seed germination of Oncidium varicosum

The culture medium used for germination of $O$. varicosum seeds (MS $1 / 2$ with $20 \mathrm{~g} \mathrm{~L}^{-1}$ of sucrose) resulted in germination rates higher than $50 \%$, with more than 300 protocorms per Petri dish. Showing that this medium is suitable for seed germination and its subsequent cultivation and that microorganism are not required for seed germination of this species. These results contrast with what has been observed for Oncidium flexuosum, in which seed germination rates higher than $30 \%$ were only achieved after inoculation with a Ceratorhiza species isolated from plant roots (Pereira et al., 2005). The differences between the results of these two experiments may be explained by the species specific requirements but also by the source of carbohydrate used in the medium. Pereira et al. (2005) used oatmeal agar, a complex carbohydrate source, without sucrose that requires microorganisms to help the plant to obtain carbon from the medium. On the other hand, using sucrose, a low complex carbohydrate source, Sorace et al. (2008) also observed asymbiotic germination in Oncidium baueri species, similar to observed in actual experiment with $O$. varicosum.
After seed germination, the in vitro culture continued with the following three stages of development: i) SWP swelling of the protocorms that became green soon after the germination (first 90 days); ii) DPL - differentiation of protocorms with the emission of the first leaves (up to 1.0$2.0 \mathrm{~cm}$ of length) (90 to 180 days of cultivation) and; iii) PLF-swelling of the pseudobulbs, emission of more leaves and of roots, which occurred between 180 and 270 days of cultivation. At the end of this last stage, plantlets had 2.0$4.0 \mathrm{~cm}$ in height and more than $50 \%$ of them were able to go for acclimatization (Figure 1F).

\section{Symbiotic culture of protocorms and plantlets of} O. varicosum

The results obtained revealed different response patterns of plants to microorganisms, which depended on the developmental stage of the plant at inoculation and on the microorganism species. In Experiment 1, where protocorms at the DPL phase were used, none of the microorganisms tested benefited their growth compared to the control treatment (MS $1 / 2$ with no microorganism) (Table 1). 
Table 1. In vitro symbiotic growth of Oncidium varicosum protocorms in $\mathrm{MS}^{1} / 2$ medium enriched with $20 \mathrm{~g} \mathrm{~L}^{-1} \mathrm{of} \mathrm{sucrose}$ and co-cultivated with different microorganisms from its roots.

\begin{tabular}{|c|c|c|c|c|}
\hline \multirow{2}{*}{ Treatment } & \multirow{2}{*}{$\begin{array}{l}\text { Plant height } \\
\text { (cm) }\end{array}$} & \multicolumn{2}{|c|}{ Number of } & \multirow{2}{*}{$\begin{array}{c}\text { Length of the } \\
\text { longest root }(\mathrm{cm})\end{array}$} \\
\hline & & leaves & roots & \\
\hline Control & $6.0 \mathrm{a}$ & $5.1 \mathrm{a}$ & $3.1 \mathrm{a}$ & $14.8 \mathrm{a}$ \\
\hline Fungus 1 & $0.0 \mathrm{~b}$ & $0.0 \mathrm{~b}$ & $0.0 \mathrm{~b}$ & $0.0 \mathrm{~b}$ \\
\hline Yeast 1 & $5.6 \mathrm{a}$ & $5.0 \mathrm{a}$ & $3.3 \mathrm{a}$ & $17.7 \mathrm{a}$ \\
\hline Yeast 2 & $5.1 \mathrm{a}$ & $5.2 \mathrm{a}$ & $2.7 \mathrm{a}$ & $17.2 \mathrm{a}$ \\
\hline $\mathrm{F}$ & $13.03 * *$ & $46.46 * *$ & $53.64 * *$ & $39.88 * *$ \\
\hline CV\% & 32.28 & 16.95 & 15.95 & 18.49 \\
\hline
\end{tabular}

Values with the same letter within each column are not significantly different from each other at $\alpha=0.01 . * *$ : significant at $1 \%$ probability. CV $(\%)=$ coefficient of variation

The treatment with Fungus 1 caused death of the protocorms likely due to the intense growth of the fungus in the culture medium, competing with the protocorms. The main cause of the excessive growth of the fungus was likely the sucrose added to the medium, as can be observed when this medium is compared with the medium without sucrose (Figure 1A). Other studies have shown that faster growth of microorganisms than plants proportionate by high nutrient and sugar availability in the substrate can hamper the growth of plants, even by those microorganisms that establish mutualistic relationships with plants, once the symbiosis is regulated by the ratio between demand of resources by organisms (plants and micro-organisms) and offer of these resources by the environment (Silva et al., 2015).

Because of this uncontrolled fungus growth in the medium supplemented with sucrose, the feasibility of other two other media was tested, the MS medium without sucrose and the OMA medium, both previously reported as suitable symbiotic conditions for other orchids species, such as Dendrobium (Silva et al., 2015) and Cyrtopodium glutiniferum (Pereira et al., 2015).

As results, the culture media had strong effect on the interaction of plants and microorganisms. Using $\mathrm{MS} 1 / 2$ culture medium with sucrose, the better response of plantlets of $O$. varicosum were observed in control without microorganisms, with the longest shoots $(5.6 \mathrm{~cm})$ and the highest number of roots/plantlet (12.1). In this culture medium microorganisms not provided benefits to the growth of $O$. varicosum shoots. However, using sucrose-free MS1 12 culture medium, the highest values of the plant characteristics evaluated were observed with microorganisms inoculated in the medium, specially using $\mathrm{B}(+)$ (Table 2). 
Table 2. Characteristics of plantlets of $O$. varicosum cultured in vitro in three different culture media inoculated with microorganisms isolated from its roots.

\begin{tabular}{|c|c|c|c|c|c|}
\hline $\begin{array}{l}\text { Medium } \\
\text { treatment }\end{array}$ & $\begin{array}{c}\text { Micro } \\
\text { organism } \\
\text { treatment }\end{array}$ & $\begin{array}{l}\text { Length of the } \\
\text { shoot } \\
\text { (cm) }\end{array}$ & $\begin{array}{c}\text { Number of } \\
\text { leaves }\end{array}$ & $\begin{array}{l}\text { Number of } \\
\text { roots }\end{array}$ & $\begin{array}{l}\text { Length of the } \\
\text { longest root } \\
\text { (cm) }\end{array}$ \\
\hline \multirow[t]{4}{*}{$\mathrm{MS}^{1} / 2$} & Control & $2.8 \mathrm{bA}$ & $3.8 \mathrm{aB}$ & $4.0 \mathrm{bB}$ & $1.1 \mathrm{bC}$ \\
\hline & Fungus 1 & $3.0 \mathrm{abA}$ & $3.0 \mathrm{bB}$ & $3.8 \mathrm{abB}$ & $1.4 \mathrm{bC}$ \\
\hline & Yeast 1 & $3.5 \mathrm{aA}$ & $4.5 \mathrm{aB}$ & $5.8 \mathrm{aB}$ & $3.8 \mathrm{aB}$ \\
\hline & $\mathrm{B}(+)$ & $4.1 \mathrm{aA}$ & $7.5 \mathrm{aA}$ & $12.1 \mathrm{aA}$ & $6.4 \mathrm{aA}$ \\
\hline \multirow[t]{4}{*}{$\mathrm{MS}^{1} / 2+\mathrm{Su}$} & Control & $5.6 \mathrm{aA}$ & $4.9 \mathrm{aB}$ & $12.1 \mathrm{aA}$ & $4.8 \mathrm{aB}$ \\
\hline & Fungus 1 & $4.4 \mathrm{aAB}$ & $7.4 \mathrm{aA}$ & $7.0 \mathrm{aB}$ & $3.3 \mathrm{abBC}$ \\
\hline & Yeast 1 & $3.0 \mathrm{aB}$ & $3.3 \mathrm{aB}$ & $5.5 \mathrm{aB}$ & $1.4 \mathrm{bC}$ \\
\hline & $\mathrm{B}(+)$ & $2.9 \mathrm{aB}$ & $4.3 \mathrm{bB}$ & $5.3 \mathrm{bB}$ & $8.2 \mathrm{aA}$ \\
\hline \multirow[t]{4}{*}{ OMA } & Control & $3.2 \mathrm{bAB}$ & $5.2 \mathrm{aA}$ & $7.2 \mathrm{bA}$ & $5.8 \mathrm{aA}$ \\
\hline & Fungus 1 & $2.7 \mathrm{bB}$ & $2.5 \mathrm{bB}$ & $2.8 \mathrm{bB}$ & $4.3 \mathrm{aA}$ \\
\hline & Yeast 1 & $4.5 \mathrm{aA}$ & $4.3 \mathrm{aAB}$ & $4.9 \mathrm{aAB}$ & $4.7 \mathrm{aA}$ \\
\hline & $\mathrm{B}(+)$ & $2.9 \mathrm{aAB}$ & $2.4 \mathrm{cB}$ & $3.3 \mathrm{bAB}$ & $1.6 \mathrm{bB}$ \\
\hline \multicolumn{6}{|c|}{$F$ values } \\
\hline \multicolumn{2}{|c|}{ Medium treatment } & $2.71 \mathrm{~ns}$ & $7.31 * *$ & $7.84 * *$ & $4.47 *$ \\
\hline \multicolumn{2}{|c|}{ Microorganism treatment } & $0.95 \mathrm{~ns}$ & $1.05 \mathrm{~ns}$ & $5.63 * *$ & $9.25 * *$ \\
\hline \multicolumn{2}{|c|}{ Medium treat. $\times$ Microorg.treat. } & $5.82 * *$ & $14.11 * *$ & $10.10^{* *}$ & $19.28 * *$ \\
\hline \multicolumn{2}{|c|}{ Coefficient of variation (\%) } & 25.9 & 24.6 & 34.5 & 31.1 \\
\hline
\end{tabular}

Small letters compare culture media within each microorganism treatment and capital letters compare microorganisms within each culture medium treatment. Values with the same letter (small or capital) are not significantly different from each other at $\alpha=0.01$. **: significant at $1 \%$ probability. MS $1 / 2$ : Murashige \& Skoog medium containing $50 \%$ of the concentration of macronutrients, without sucrose; MS $1 / 2+$ Su: MS medium with sucrose; OMA: Oatmealagar medium.

The $\mathrm{B}(+)$ co-cultivated with plantlets of $O$. varicosum in sucrose-free MS medium resulted in increases in shoot development, height of shoots $(46.3 \%)$ and number of leaves $(97.4 \%)$, but especially in development of roots, number of roots per plantlet $(202.5 \%)$ and longer roots $(482 \%)$ compared with asymbiotic culture control at the same culture medium. In addition, the results obtained within this bacterium sucrose-free $\mathrm{MS}^{1} / 2$ were similar or better than obtained with plantlets of $O$. varicosum cultivated under asymbiotic MS $1 / 2$ with sucrose, proving the efficiency of this microorganism to provide the development of plantlets in vitro.

Co-cultivation of plants and microorganisms at the PLF stage (shoots with pseudobulbs and leaves) at in vitro rooting stage and previous to greenhouse acclimatization generating interesting results than inoculation at the protocorm stage (DPL) of in vitro development.
Dan et al. (2012) observed that plantlets of D. nobile and $D$. candidum were benefited by the inoculation of five fungi strains with an increase of $100 \%$ in height and weight compared to the non-inoculated control. Use of symbiotic germination in Cyrtopodium glutiniferum also resulted in higher seed germination and in vitro development of seedlings using Epulorhiza sp. as symbiont (Guimarães et al., 2013). In oppose, in the orchid species Grammatophyllum speciosum and D. draconis the use of putative symbiotic cultivation using eight isolates of the microorganisms Tulaneslla and Epulorhiza in OMA medium did not result in better development of seedlings when compared with asymbiotic cultivation in $\mathrm{MS} 1 / 2$ culture medium (Nontachaiyapoom et al., 2011).

The specificity of relation of microorganism-plant also influences the successful orchid mycorrhization. Inoculation of protocorms of Dendrobium candidum 
with 40 strains of Orchidaceae mycorrhizal fungi resulted in only $7.5 \%$ of protocorm survival, but the survival rate increased to $45 \%$ when plantlets were used. These positive results, however, were observed with only 5 out of the 40 mycorrhizal fungi strains used (Dan et al., 2012). Furthermore, in Oncidium flexuosum only seeds inoculated with a specific M2 isolate of Ceratorrhiza species in OMA medium without an exogenous carbohydrate supply resulted in germination and protocorm development (Pereira et al., 2005).

\section{Acclimatization of plantlets in greenhouse}

The plantlets obtained from previous experiment were successfully acclimatized in greenhouse conditions. The evaluation of plantlets during ex vitro acclimatization phase resulted in better performance of $O$. varicosum plants when from co-cultivated previously with microorganisms, compared to asymbiotic in vitro cultivation. The three microorganisms isolated and used at in vitro rooting stage proved it efficiency for this acclimatization phase, resulting in a better performance of the plantlets, according with the culture media used.

Interestingly, the best culture medium for in vitro development of plantlets of $O$. varicosum with $\mathrm{B}(+)$ microorganism, the free-sucrose $\mathrm{MS}^{1} / 2$, has different results on ex vitro conditions of plants development (Figure 2).
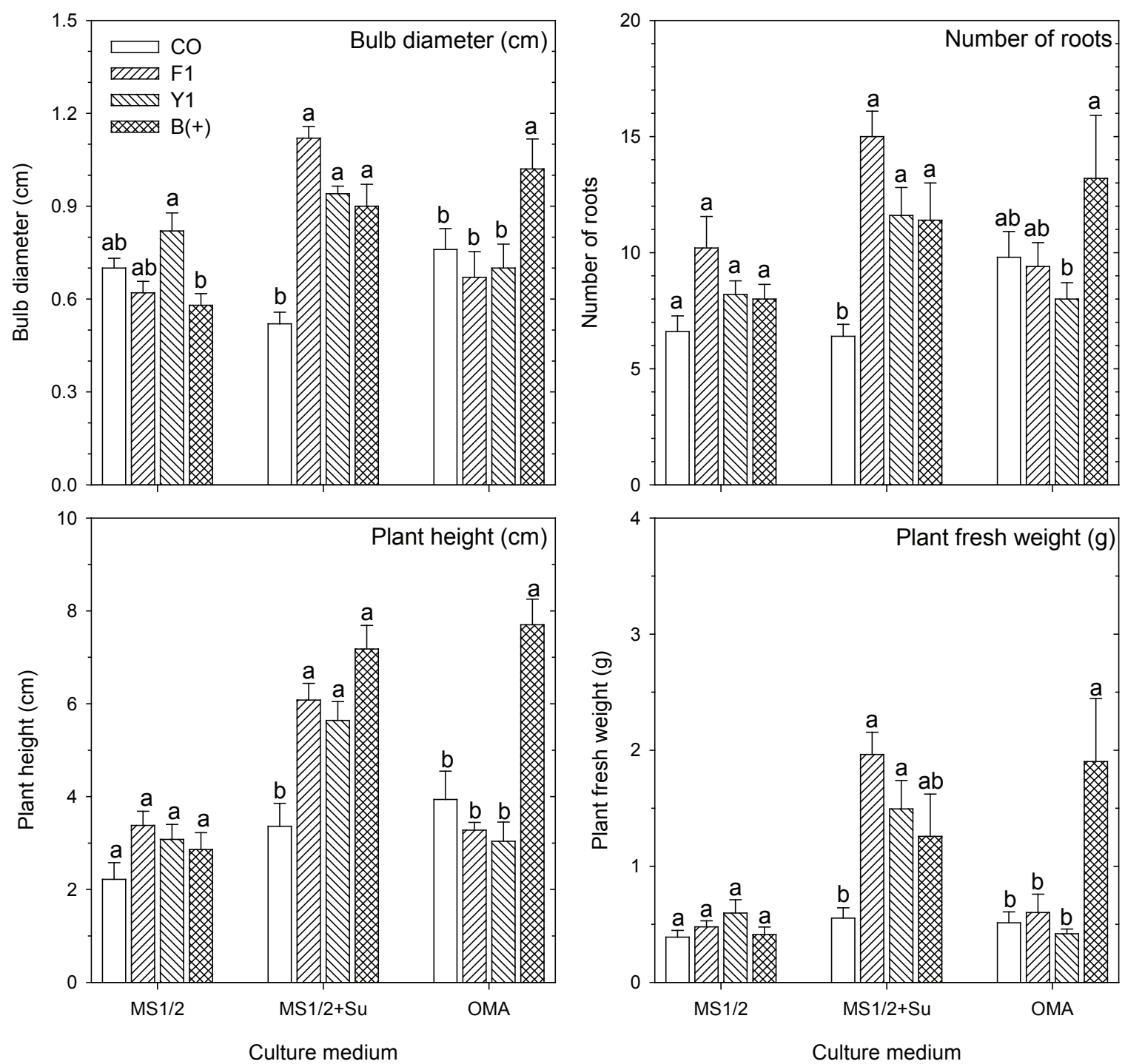

Figure 2. Bulb diameter, number of roots, plant height and plant fresh weight of $O$. varicosum plantlets cultivated for 120 days on three different culture media inoculated with microorganisms. Control treatment without microorganisms (CO), fungus (F1), yeast (Y1) and gram-positive bacteria (B+) used for co-cultivation with O. varicosum. MS culture medium without sucrose (MS) and with sucrose (MS+Su), and Oatmeal culture medium (OMA). 
This means that absence of a source of carbohydrates in the culture medium is not good for acclimatization stage and ex vitro development of $O$. varicosum, since when in co-cultivation with $\mathrm{B}(+)$ microorganism. Interestingly, all microorganisms used $(\mathrm{F} 1, \mathrm{Y} 1$ and $\mathrm{B}(+))$ showed positive results for ex vitro development of plants of $O$. varicosum on $\mathrm{MS}^{1} 12$ sucrose medium for all development parameters evaluated (Figure 2), differing from the asymbiotic cultivation in this same culture medium. In OMA culture medium, only co-cultivation with microorganism $\mathrm{B}(+)$ resulted in significant increases of about $35 \%$ in pseudobulb diameter and number of roots, in $95 \%$ in plant height and in $270 \%$ in plant fresh weight compared to plants grown in the same medium without microorganisms.

Most adult green orchids have no strong associations with mycorrhizal fungi (Rasmussen and Whigham, 2002) and the effects of using different symbiotic microorganism species in this phase do not always result in benefits for the plant development (Reiter et al., 2018). However, in vitro seedlings could benefit from symbiotic relationships which help overcome abiotic and biotic stresses during the acclimatization phase (Silva et al., 2017), including in natural environments where the non-favourable conditions for plant growth are recurrent along the year. The microorganisms associated with orchid roots act to promote growth by fixing atmospheric nitrogen, improving mineral nutrition, producing plant growth regulators, controlling phytopathogens and thus helping plants to survive to adverse environmental conditions (Tsavkelova, 2011; Rasmussen and Rasmussen, 2014; Silva et al., 2015). The use of the diazotrophic bacteria Herbaspirillum frisigense from orchid roots were reported benefit the growth of acclimatized plantlets of Cymbidium sp., increasing total dry matter and higher contents of $\mathrm{N}$ and $\mathrm{P}$ in dry matter (Gontijo et al. 2018).

It has been suggested that the use of symbiotic microorganisms during germination can result in the reduction of micropropagation costs. Guimarães et al. (2013) argued that the OMA medium is less expensive than any commercial medium used for asymbiotic culture, like Knudson C, for example. However, only this advantage may not be enough to justify the use of symbiotic culture for commercial orchid propagation as the culture medium is one of the least expensive components of a micropropagated plantlet (Chen, 2016) and the increase in labour ( $60 \%-75 \%$ of costs of a micropropagated plantlet) (Cardoso et al. 2018) to perform symbiotic germination of orchids could represent an expansive and laborious technique. However, if symbiotic germination promotes increases of efficiency in seedling development, as proved for in vitro and ex vitro development of $O$. varicosum, the technique could be a realistic way to produce low-cost micropropagated plantlets.

This technique has wide interesting for the production of wild species aiming at programs of reintroduction to nature and for better understanding of the interaction between plant-microorganism, and could be the only-way for those species whose in vitro asymbiotic germination is not possible (Khamchatra et al., 2016). In our study, around
10 plantlets previously inoculated with $\mathrm{B}(+)$ and with six months of acclimatization were used for restoration of a riparian forest in Araras-SP, Brazil. After two years of cultivation as epiphytic in wild Camptotecha acuminata (Nyssaceae), all $O$. varicosum plants survived and produced new roots and shoots (Figure 1G).

The use of microorganisms at rooting stage of micropropagation of orchids could be combined with in vitro pre-acclimatization in greenhouse culture, similar to use for gerbera micropropagation (Cardoso et al. 2013) to increase efficiency and reduce the costs of micropropagated seedlings.

\section{Conclusions}

The use of microorganisms isolated from roots of adult plants followed by re-inoculation on in vitro seedlings of the same species can be used as a method for improving and accelerating the acclimatization of in vitro-derived plantlets, for both, commercial production and nature conservation and restoration. The technique developed in this study proved that not only mychorrhizal fungus, but also some bacteria could be potential for application in orchid cultivation. Only plantlets co-cultivated with $\mathrm{B}(+)$ bacteria in OMA culture medium showed better performance under ex vitro conditions.

\section{Author contributions}

GAB 0000-0001-5391-4226 and JCC $^{0000-0001-6578-1723}$ : conceived the study and planned the experiments. GAB and $\mathbf{A} \mathbf{V}^{0000-0002-4967-}$ 6218: performed the experiments and analyses and processed the experimental data. JCC and EDM ${ }^{0000-0002-6465-6397: ~ d e s i g n e d ~ t h e ~}$ figures and wrote the manuscript with input from all authors.

\section{Acknowledgements}

JCC and EDM thanks CNPq/Brazil for financial support the Processes 458670/2014-6 and JCC for the 304174/2015-7 (CNPq/ Brazil). All authors thank to Marcia M. Rosa Magri to help with characterization of gram-positive bacteria.

\section{References}

CARDOSO, J.C.; ROSSI, M.L.; ROSALEM, I.B.; SILVA, J.A.T. An alternative to optmizing the micropopagation of gerbera. Scientia Horticulturae, v.164, p.616-624, 2013. DOI: http://dx.doi.org/10.1016/j.scienta.2013.10.022

CARDOSO, J.C.; SILVA, J.A.T; VENDRAME, W.A. Impacts of deforestation on some orchids of Sao Paulo State, Brazil. Natureza \& Conservação, v.14, n.1, p.28-32, 2016. DOI: http://dx.doi.org/10.1016/j.ncon.2016.02.001.

CARDOSO, J.C. Ionocidium 'Cerrado 101': intergeneric orchid hybrid with high quality of blooming. Ornamental Horticulture, v.23, n.3, p.351-356, 2017. DOI: http:// dx.doi.org/10.14295/oh.v23i3.1110 
CARDOSO, J.C.; GERALD, L.T.S.; SILVA, J.A.T. Micropropagation in the Twenty-First Century. Plant Cell Culture Protocols, p.17-46, 2018. DOI: http://dx.doi. org/10.1007/978-1-4939-8594-4_2

CHEN, C. Cost analysis of plant micropropagation of Phalaenopsis. Plant Cell Tissue and Organ Culture, v.126, n.1, p.167-175, 2016. DOI: 10.1007/s11240-0160987-4

DAN, Y.; MENG, Z.X.; GUO, S.X. Effects of forty strains of Orchidaceae mycorrhizal fungi on growth of protocorms and plantlets of Dendrobium candidum and $D$. nobile. African Journal of Microbiology Research, v.6, n.1, p.1411-1416, 2012. DOI: http://dx.doi.org/10.5897/ ajmr 11.442

DEARNALEY, J.D.W.; CAMERON, D.D. Nitrogen transport in the orchid mycorrhizal symbiosis - further evidence for a mutualistic association. New Phytologist, v.213, n.1, p.10-12, 2016. DOI: http://dx.doi.org/10.1111/ nph. 14357

FARIA, R.T.; COLOMBO, R.C. Oncidium: a orquídea em expansão no cenário florícola. Horticultura Brasileira, v.33, n.4, p.533-533, 2015. DOI: http://dx.doi.org/10.1590/ s0102-053620150000400022

GONTIJO, J.B.; ANDRADE, G.V.S.; BALDOTTO, M.A.; BALDOTTO, L.E.B. Bioprospecting and selection of growth-promoting bacteria for Cymbidium sp. Orchids. Scientia Agricola, v.75, n.5, p.368-374, 2018. DOI: http:// dx.doi.org/10.1590/1678-992x-2017-0117

GUIMARÃES, F.A.R.; PEREIRA, M.C.; FELÍCIO, C.S.; TORRES, D.P.; OLIVEIRA, S.F.; VELOSO, T.G.R.; KASUYA, M.C.M. Symbiotic propagation of seedlings of Cyrtopodium glutiniferum Raddi (Orchidaceae). Acta Botanica Brasilica, v.27, n.3, p.590-596, 2013. DOI: http://dx.doi.org/10.1590/s0102-33062013000300016

IGNATOVA, L.V.; BRAZHNIKOVA, Y.V.; BERZHANOVA, R.Z.; MUKASHEVA, T.D. Plant growthpromotion and antifungal activity of yeasts from dark chestnut soil. Microbiological Research, v.175, p.78-83, 2015. DOI: http://dx.doi.org/10.1016/j.micres.2015.03.008

KHAMCHATRA. N.M..; DIXON, K.; CHAYAMARIT K.; APISITWANICH, S.; TANTIWIWAT, S. Using in situ seed baiting technique to isolate and identify endophytic and mycorrhizal fungi from seeds of a threatened epiphytic orchid, Dendrobium friedericksianum Rchb.f. (Orchidaceae). Agriculture and Natural Resources, v.50, n.1, p.8-13 2016. DOI: http://dx.doi.org/10.1016/j. anres.2016.01.002
JIN, Z.; LI, D.; LIU, T.; YU, F.; ZHANG, Z.; SU, C.; WANG, Y.; GUO, Q.; LIU, Z. Cultural endophytic fungi associated with Dendrobium officinale: identification, diversity estimation and their antimicrobial potential. Current Science, v.112, n.8, p.1690-1697, 2017. DOI: http://dx.doi.org/10.18520/cs/v112/i08/1690-1697

MURASHIGE, T.; SKOOG, F. A revised medium for rapid growth and bioassay with tobacco tissue cultures. Physiologia Plantarum, v.15, n.3, p.473-497, 1962. DOI: http://dx.doi.org/10.1111/j.1399-3054.1962.tb08052.x.

NONTACHAIYAPOOM, S.; SASIRAT, S.; MANOCH, L. Symbiotic seed germination of Grammatophyllum speciosum Blume and Dendrobium draconis Rchb. f., native orchids of Thailand. Scientia Horticulturae, v.130, n.1, p.303-308, 2011. DOI: http://dx.doi.org/10.1016/j. scienta.2011.06.040

NOVELLO, M.; RODRIGUES, J.F.; PINHEIRO, F.; OLIVEIRA, G.C.X.; VEASEY, E.A.; KOEHLER, S. Simple-sequence repeat markers of Cattleya coccinea (Orchidaceae), an endangered species of the Brazilian Atlantic Forest. Genetics and Molecular Research, v.12, n.3, p.3274-3278, 2013. DOI: http://dx.doi. org/10.4238/2013.september.3.3

PEREIRA, O.L.; KASUYA, M.C.M.; ROLLEMBERG, C.L.; BORGES, A.C. Indução in vitro da germinação de sementes de Oncidium flexuosum (Orchidaceae) por fungos micorrízicos rizoctonióides. Revista Brasileira de Ciência do Solo, v.29, n.2, p.199-206, 2005. DOI: http:// dx.doi.org/10.1590/s0100-06832005000200005

PEREIRA, M.C.; ROCHA, D.I.; VELOSO, T.G.R.; PEREIRA, O.L.; FRANCINO, D.M.T.; MEIRA, R.M.S.A.; KASUYA, M.C.M. Characterization of seed germination and protocorm development of Cyrtopodium glutiniferum (Orchidaceae) promoted by mycorrhizalfungi Epulorhiza spp. Acta Botanica Brasilica, v.29, n.4, p.567-574, 2015. DOI: http://dx.doi.org/10.1590/0102-33062015abb0078

PEREIRA, G.; SUZ, L.M.; ALBORNOZ, V.; ROMERO, C.; GARCIA, L.; LEIVA, V.; ATALA, C. Mycorryzal fungi associated with Codonorchis iessonii (Brongn) Lindl., a terrestrial from Chile. Gayana Botánica, v.75, n.1, p.447-458, 2018. DOI: http://dx.doi.org/10.4067/s071766432018000100447

PINHEIRO, F.; CAZZOLINO, S.; BARROS, F.; GOUVEIA, T.M.Z.M.; SUZUKI, R.M.; FAY, M.F. \& PALMA-SILVA, C. Phylogeographic structure and outbreeding depression reveal early stages of reproductive isolation in the neotropical orchid Epidendrum denticulatum. Evolution, v.67, n.7, p.2024-2039, 2013. DOI: http://dx.doi.org/10.1111/evo.12085 
RASMUSSEN, H.N.; WHIGHAM, D.F. Phenology of roots and mycorrhiza in orchid species differing in phototrophic strategy. New Phytologist, v.154, n.3, p.797-807, 2002. DOI: http://dx.doi.org/10.1046/j.14698137.2002.00422.x

RASMUSSEN, H.N.; RASMUSSEN, F.N. Seedling mycorrhiza: a discussion of origin and evolution in Orchidaceae. Botanical Journal of the Linnean Society, v.175, n.3, p.313-327, 2014. DOI: http://dx.doi.org/10.1111/ boj. 12170 .

REITER, N.; LAWRIE, A.C.; LINDE, C.C. Matching symbiotic associations of an endangered orchid to habitat to improve conservation outcomes. Annals of Botany, p.947959, 2018. DOI: http://dx.doi.org/10.1093/aob/mcy094

SILVA, C.S.; GARCÊS DE ARAÚJO, L.; SOUSA, K.C.I.; BORBA DE CARVALHO, J.C.; GONÇALVES, L.A.; CARNEIRO, L.L. Cultivo in vitro de Epidendrum nocturnum (Orchidaceae) ocorrente no cerrado da região centro-oeste. Rodriguésia, v.67, n.4, p.1083-1091, 2016. DOI: http://dx.doi.org/10.1590/2175-7860201667418

SILVA, J.A.T; TSAVKELOVA, E.A.; ZENG, S.; NG, T.B.; PARTHIBHAN, S.; DOBRÁNSZKI, J.; CARDOSO, J.C.; RAO, M.V. Symbiotic in vitro seed propagation of Dendrobium: fungal and bacterial partners and their influence on plant growth and development. Planta, v.242, n.1, p.1-22, 2015. DOI: http://dx.doi.org/10.1007/s00425-015-2301-9
SILVA, J.A.T; HOSSAIN, M.M.; SHARMA, M.; DOBRÁNSZKI, J.; CARDOSO, J.C.; ZENG, S. Acclimatization of in vitro-derived Dendrobium. Horticultural Plant Journal, v.3, n.3, p.110-124, 2017. DOI: http://dx.doi.org/10.1016/j.hpj.2017.07.009

SORACE, M.; FARIA, R.T.; DAMASCENOJUNIOR, C.V.; GOMES, G.P.; BARBOSA, C.M.; VIEIRA, F.G.N.; SILVA, G.L.; TAKAHASHI, L.S.A.; SCHNITZER, J.A. Crescimento in vitro de Oncidiumbaueri (Orchidaceae) em diferentes concentrações de macronutrientes e sacarose. Semina: Ciências Agrárias, v.29, n.4, p.775-781, 2008. DOI: http://dx.doi.org/10.5433/16790359.2008v29n4p775

TSAVKELOVA, E.A. Bacteria associated with orchid roots. Bacteria in Agrobiology: Plant Growth Responses, p.221-259, 2011. DOI: http://dx.doi.org/10.1007/978-3642-20332-9_11

WU, K.; ZENG, S.; LIN, D.; TEIXEIRA DA SILVA, J.A.; BU, Z.; ZHANG, J.; DUAN, J. In vitro propagation and reintroduction of the endangered Renanthera imschootiana Rolfe. Plos One, v.9, n.10, p.1-12, 2014. DOI: http:// dx.doi.org/10.1371/journal.pone.0110033 